Zeszyty Naukowe Szkoły Głównej Gospodarstwa Wiejskiego

Ekonomika i Organizacja Gospodarki Żywnościowej nr 110, 2015: 81-95

Piotr Nowaczyk

Wydział Ekonomiczny

Zachodniopomorski Uniwersytet Technologiczny w Szczecinie

\title{
Analiza wpływu przystąpienia Polski do Unii Europejskiej na krajowe rybołówstwo morskie
}

\section{Wstęp}

$\mathrm{Z}$ dniem 01.05.2004 roku po wielu latach negocjacji akcesyjnych Polska stała się pełnoprawnym członkiem Unii Europejskiej. Warunkiem integracji było przyjęcie dorobku prawnego wspólnot europejskich, w tym regulacji dotyczących Wspólnej Polityki Rybackiej (WPR) ${ }^{1}$. Polski sektor rybołówstwa morskiego stanowił przestarzałą gałąź gospodarki niespełniającą wymogów stawianych przed rybołówstwem europejskim. Wymagał restrukturyzacji, a szansy na jej przeprowadzenie upatrywano w członkostwie naszego kraju w Unii Europejskiej. Narzędziem realizacji planów przekształcenia polskiego rybołówstwa miały być unijne środki sektorowych programów operacyjnych dedykowanych rybactwu.

Rybołówstwo morskie stanowi ważną część sektora rybackiego. Niezbędnymi elementami umożliwiającymi jego funkcjonowanie, prócz dostępu do łowisk, jest flota rybacka oraz sieć portów i przystani rybackich. Od lat 80. ubiegłego stulecia polskie rybołówstwo morskie borykało się z coraz większymi problemami. Ograniczony dostępu do łowisk światowych, na skutek wprowadzenia stref połowowych i opłat za łowienie w strefach brzegowych, wymusił wzrost zainteresowania połowami w wodach morskich Bałtyku [Malkowska 2010, s. 275-285]. W konsekwencji rosnący potencjał połowowy stał się za duży w stosunku do zasobów ryb bałtyckich. Kwoty połowowe przyznawane jednostkom rybackim stawały się coraz mniejsze, co negatywnie odbijało się na rentowności rybołówstwa morskiego. W celu zmniejszenia presji połowowej na ograniczo-

\footnotetext{
${ }^{1}$ Więcej na temat WPR zob. W. Brocki 2000: Ogólna charakterystyka wspólnej polityki rybackiej, [w]: Wybrane zagadnienia wspólnej polityki rybackiej w Unii Europejskiej - potrzeby i możliwości adaptacji wspólnej polityki rybackiej przez polska gospodarkę rybna, (red.) J. Zieziula, Wydawnictwo Ekspert - SITR, Koszalin, s. 9-17.
} 
ne zasoby bałtyckie, od 2004 roku rozpoczął się proces redukcji polskiej floty rybackiej. Jego głównym zadaniem miało być zwiększenie połowów przypadających na jednostkę rybacka, a proces wycofywania jednostek połowowych finansowany był ze środków unijnych.

Porty i przystanie rybackie były strukturami zaniedbanymi inwestycyjne. Infrastruktura portowa była zdekapitalizowana. Brakowało nowoczesnych urządzeń przeładunkowych oraz obiektów magazynowych i socjalnych. Wpływało to negatywnie na funkcjonowanie portów i przystani rybackich [Grzelakowski 2002, s. 9-24], zmniejszało bezpieczeństwo postoju jednostek rybackich, utrudniało przeładunek połowów oraz ograniczało możliwości przechowywania poławianych $\mathrm{ryb}^{2}$. Wraz z dołączeniem Polski do struktur unijnych rozpoczął się proces modernizacji portów $\mathrm{w}$ skali niemającej precedensu w powojennej historii naszego kraju.

Rybołówstwo realizowane w wodach morskich Bałtyku stanowi ważną gałąź gospodarki narodowej. Mimo regresu rybołówstwa morskiego rybacy dostarczają blisko połowę ryb spożywanych w Polsce. Wśród mięs ryby stanowią ważny składnik diety Polaków, choć niedominujący. Wielkość spożycia ryb w Polsce wykazuje zróżnicowanie. W latach 2008-2012 spożycie zmniejszało się, aby w 2013 roku wzrosnąc ${ }^{3}$. Czynnikiem obniżającym spożycie ryb jest ich relatywnie wysoka cena. Z drugiej strony wzrost zamożności Polaków powinien zwiększać konsumpcję przetworów rybnych [Pieńkowska i Hryszko 2013, s. 26-30].

Dotychczasowe analizy na temat wpływu członkostwa Polski w Unii Europejskiej na restrukturyzację rybołówstwa morskiego są niekompletne i wymagają uzupełnienia. Wysoka dynamika zmian zachodzących w rybołówstwie morskim wymusza ciaggłą aktualizację wiedzy.

Celem artykułu jest analiza wpływu integracji europejskiej na restrukturyzacje krajowego rybołówstwa morskiego realizowanego na wodach Bałtyku.

W niniejszym artykule przedstawiono wielkość środków unijnych przeznaczonych na restrukturyzację polskiego sektora rybackiego, w tym rybołówstwa morskiego, skalę redukcji polskiej floty rybackiej oraz jej wpływ na stopę bezrobocia, zmiany w wielkości połowów przypadających na jednostkę rybacką, informację na temat wielkości nakładów inwestycyjnych na modernizację portów

\footnotetext{
${ }^{2}$ Sektorowy Program Operacyjny „Rybołówstwo i przetwórstwo ryb 2004-2006”.

${ }^{3} \mathrm{~W}$ latach 2008-2012 wielkość spożycia ryb w Polsce zmniejszyła się z 13,5 do 11,7 kg na osobę. W 2013 roku spożycie wzrosło do poziomu ponad $12 \mathrm{~kg}$ na osobę. Zob. K. Hryszko, Polacy nadal jedzq mało ryb. Szanse na znaczqcy wzrost spożycia sq niewielkie, http://www.biznes.newseria.pl/news/polacy_nadal_jedza_malo,p1522677165 (data dostępu: 20.05.2015).
} 
i przystani rybackich oraz potrzebę dalszych zmian w rybołówstwie morskim. Zakończenie stanowią wnioski z przeprowadzonej w artykule analizy.

Praca bazuje na literaturze przedmiotu oraz materiałach opublikowanych w latach 2005-2012. W okresie tym przeprowadzono liczne badania empiryczne, głównie ankietowe i wywiady pogłębione. Skierowane były one do podmiotów rybołówstwa morskiego, tj. rybaków oraz przedstawicieli podmiotów zarządzających portami i przystaniami rybackimi.

\section{Restrukturyzacja polskiego sektora rybackiego}

Plan restrukturyzacji polskiego sektora rybackiego na lata 2004-2006 zawarty był w Sektorowym Programie Operacyjnym „Rybołówstwo i przetwórstwo ryb 2004-2006” (SPO „Ryby 2004-2006”), a na lata 2007-2013 w Programie Operacyjnym „Zrównoważony rozwój sektora rybołówstwa i nadbrzeżnych obszarów rybackich 2007-2013” (PO „Ryby 2007-2013) ${ }^{4}$. Programy te przewidywały dofinansowanie polskiego rybołówstwa łączną kwotą 1260736 tys. euro (tab. 1). Na restrukturyzację rybołówstwa morskiego zarezerwowano 454996 tys. euro, co odpowiadało przeszło 36\% ogólnej wielkości środków.

\section{Tabela 1}

Wielkość środków unijnych [tys. euro] przeznaczonych na restrukturyzację polskiego rybołówstwa morskiego w latach 2004-2013

\begin{tabular}{|c|c|c|c|c|c|c|}
\hline \multirow{2}{*}{ Program } & \multicolumn{5}{|c|}{ Restrukturyzacja polskiego sektora morskiego } \\
\cline { 2 - 7 } & $\begin{array}{c}\text { Flota } \\
\text { rybacka }\end{array}$ & $\begin{array}{c}\text { Porty } \\
\text { i przystanie } \\
\text { rybackie }\end{array}$ & Pozostałe & Suma & \multicolumn{2}{|c|}{$\begin{array}{c}\text { Flota rybacka + porty } \\
\text { i przystanie rybackie }\end{array}$} \\
\cline { 3 - 7 } & 103896 & 42341 & 135708 & 281945 & 146237 & 51,87 \\
\hline SPO [tys. euro] & 1037 tys. euro & $\%$ \\
\hline PO [tys. euro] & 164737 & 144022 & 670031 & 978790 & 308759 & 31,54 \\
\hline Suma [tys. euro] & 268633 & 186363 & 805739 & 1260736 & 454996 & 36,09 \\
\hline
\end{tabular}

Objaśnienia: SPO - „Ryby 2004-2006”, PO - „Ryby 2007-2013.

Źródło: Obliczenia własne na podstawie: Sektorowego Programu Operacyjnego „Rybołówstwo i przetwórstwo ryb 2004-2006"; Informacji o postępach wdrażania Programu Operacyjnego „Zrównoważony rozwój sektora rybołówstwa i nadbrzeżnych obszarów rybackich 2007-2013" (stan na styczeń 2014 roku).

\footnotetext{
${ }^{4}$ Więcej na temat finansowania sektora rybackiego ze środków unijnych: B. Pieńkowska, 2009: Pomoc finansowa dla sektora rybołówstwa w okresie programowania 2007-2013, Wiadomości Rybackie 5-6(169), s. 12-13.
} 
Rybołówstwo morskie stanowiło więc sektor rybacki, który otrzymał największe dofinansowanie ${ }^{5}$.

Tak duża wielkość środków skoncentrowana na finansowaniu rybołówstwa morskiego wynikała z jego olbrzymich potrzeb. Potencjał floty rybackiej był zbyt duży w stosunku do zmniejszających się zasobów Morza Bałtyckiego i wymagał redukcji oraz działań łagodzących skutki złomowania jednostek pływających. $\mathrm{Z}$ kolei porty i przystanie rybackie w większości były zaniedbane. Infrastruktura portowa była zdekapitalizowana. Brakowało nowoczesnych urządzeń przeładunkowych, pomieszczeń magazynowych oraz obiektów sanitarnych. Rynek rybny był słabo zorganizowany.

\section{Restrukturyzacja polskiej floty rybackiej}

Od lat 80. ubiegłego stulecia do momentu akcesji Polski do Unii Europejskiej, czyli do roku 2004, liczebność polskiej floty rybackiej pozostawała na dość wyrównanym poziomie [Blady i Netzel 2005, s. 12-15]. W 2004 roku w polskim rybołówstwie bałtyckim zarejestrowanych było 1408 jednostek rybackich, a przy ich obsłudze zatrudniano blisko 12 tys. osób ${ }^{6}$ (tab. 2). W 2004 roku rozpoczął się proces wycofywania jednostek rybackich z eksploatacji. Głównym motywem, którym kierowali się armatorzy przy podejmowaniu decyzji o odejściu z zawodu, była niska dochodowość połowów, przy jednocześnie wysokich rekompensatach wypłacanych za kasację jednostki rybackiej [Marciniak 2008, s. 12-187]. Niska i stale pogarszająca się dochodowość działalności była następstwem zmniejszających się zasobów ryb, szczególnie gatunków cennych, decydujących o opłacal-

\footnotetext{
${ }^{5}$ Inne sektory rybołówstwa, które zostały wyodrębnione w programach operacyjnych to m.in.: przetwórstwo rybne, rybołówstwo śródlądowe i akwakultura, rozwój obszarów zależnych od rybołówstwa, ochrona środowiska, organizacja rynku rybnego. Zob. więcej: SPO „Ryby 2004-2006” oraz PO „Ryby 2007-2013”.

${ }^{6}$ Zatrudnienie w sektorze rybackim obejmuje załogę statków rybackich oraz osoby pośrednio związane $\mathrm{z}$ działalnością podstawową (połowowa). Przy obliczeniach podzielono jednostki rybackie na grupy opierając się na kryterium wielkości (długości). Założono przy tym, że minimalne zatrudnienie na jednostkach o długości poniżej $17 \mathrm{~m}$ to dwie osoby, na jednostkach o długości 17-20m - cztery osoby, na jednostkach o długości 20-25 m - sześć osób, a na jednostkach powyżej $25 \mathrm{~m}$ - osiem osób. W przypadku osób pośrednio zatrudnionych w sektorze rybackim założono, iż na jednego rybaka poławiającego na otwartych wodach Bałtyku przypadają 3 osoby zatrudnione w zawodach towarzyszących, a na jednego rybaka poławiającego na wodach Zalewu Szczecińskiego oraz Zalewu Wiślanego - 0,3 osoby. Niższe wartości odnoszące się do akwenów zalewowych wynikają z mniejszych połowów dokonywanych na tych wodach. Zob. I Dunin-Kwinta, 2000: Wielowariantowy model redukcji nakładu polowowego z uwzględnieniem skutków społecznych $w$ rejonach nadmorskich, [w]: Wybrane..., op. cit., s. 47-48 oraz Z. Polański, 2000: Polskie rybolówstwo przybrzeżne, MIR, Gdynia 2000, s. 52-56.
} 
Tabela 2

Liczba jednostek rybackich (sztuki) oraz zatrudnienie (osoby) w sektorze połowów rybackich w Polsce w 2004 oraz w 2013 roku

\begin{tabular}{|c|c|c|c|c|c|c|c|}
\hline \multirow{3}{*}{\multicolumn{2}{|c|}{$\begin{array}{l}\text { Liczebność } \\
\text { floty rybackiej } \\
\text { z podziałem na } \\
\text { klasy długości }\end{array}$}} & \multicolumn{4}{|c|}{ Lata } & \multirow{4}{*}{$\begin{array}{c}\text { Zmiana liczebno- } \\
\text { ści jednostek } \\
\text { rybackich } \\
2013 / 2004 \\
{[\%]} \\
-39,0\end{array}$} & \multirow{4}{*}{\begin{tabular}{|c}
$\begin{array}{c}\text { Zmiana } \\
\text { wielkości } \\
\text { zatrudnienia } \\
2013 / 2004 \\
{[\%]}\end{array}$ \\
$-39,0$
\end{tabular}} \\
\hline & & \multicolumn{2}{|c|}{2004} & \multicolumn{2}{|c|}{2013} & & \\
\hline & & $\begin{array}{c}\text { Liczba } \\
\text { a }\end{array}$ & $\begin{array}{c}\text { Zatrud- } \\
\text { nienie }\end{array}$ & $\begin{array}{c}\text { Liczba } \\
\text { jednostek }\end{array}$ & $\begin{array}{c}\text { Zatrud- } \\
\text { nienie }\end{array}$ & & \\
\hline \multirow{2}{*}{$<17$} & Zalewy & 308 & 801 & 188 & 489 & & \\
\hline & $\begin{array}{c}\text { Morze } \\
\text { Bałtyckie }\end{array}$ & 683 & 4098 & 467 & 2802 & $-31,6$ & $-31,6$ \\
\hline \multicolumn{2}{|c|}{$17-20$} & 205 & 2460 & 75 & 900 & $-63,4$ & $-63,4$ \\
\hline \multicolumn{2}{|c|}{$20-25$} & 176 & 3168 & 41 & 738 & $-76,7$ & $-76,7$ \\
\hline \multicolumn{2}{|r|}{$>25$} & 28 & 672 & 24 & 576 & $-14,3$ & $-14,3$ \\
\hline \multicolumn{2}{|c|}{ Razem } & 1408 & 11199 & 795 & 5505 & $-43,5$ & $-50,8$ \\
\hline
\end{tabular}

Objaśnienie: Zalewy - Zalew Szczeciński oraz Zalew Wiślany.

Źródło: Opracowanie własne na podstawie: Rejestr statków rybackich, I. Dunin-Kwinta, 2000: Wielowariantowy..., op. cit., Z. Polański, 2000: Polskie..., op. cit.

ności połowów. Z kolei pochodzące ze środków unijnych rekompensaty wypłacane armatorom należały do najwyższych w Unii Europejskiej. Ich wielkość była wyższa od wartości rynkowej wycofywanych jednostek rybackich. Dlatego też stanowiły ważny czynnik skłaniający armatorów do podjęcia ostatecznej decyzji o kasacji jednostek rybackich ${ }^{7}$. Proces restrukturyzacji polskiej floty rybackiej był nieuchronny. Środki z Unii Europejskiej tylko go przyśpieszyły, łagodząc przy tym skutki. Pojawiające się trudności były przejściowe i niewspółmiernie małe do korzyści ${ }^{8}$.

\footnotetext{
${ }^{7}$ Potwierdzają to m.in. dane dotyczące połowów oraz wielkości polskiej floty rybackiej w okresie 20-30 lat poprzedzających członkostwo Polski w Unii Europejskiej. Od połowy lat 80. (kiedy to notowano rekordowe połowy) zasoby ryb decydujące o rentowności działalności, tj. dorszy, zaczęły ulegać zmniejszaniu. W końcu ich połowy obniżyły się radykalnie, osiągając w niektórych latach rekordowo niskie poziomy. Jednakże w tym samym czasie wielkość floty rybackiej pozostawała na dość stabilnym poziomie, ulegając tylko niewielkim zmianom. Przy tym ich modernizacja zwiększała możliwości połowowe, co pogłębiało tylko problem nadmiaru nakładu połowowego. Dopiero możliwość otrzymania wysokiej rekompensaty za likwidacje miejsca pracy gwałtownie przyspieszyła proces dostosowywania wielkości floty rybackiej do zmniejszających się zasobów ryb.

${ }^{8}$ Do najczęściej wymienianych negatywnych konsekwencji redukcji polskiej floty rybackiej zaliczamy wysokość rekompensat uzależnionych od wieku jednostki i jej wielkości oraz brak właści-
} 
W rezultacie w 2013 roku polska flota rybacka liczyła 795 statków, w ciągu 10 lat zmniejszyła się więc o 613 jednostek, co w ujęciu względnym oznaczało redukcję o blisko $44 \%$. W związku z tak głęboką redukcją jednostek pływających zatrudnienie w sektorze połowów powinno zmniejszyć się o 6494 osoby, czyli o przeszło połowę w porównaniu z rokiem $2004^{9}$. Jednakże w rzeczywistości skala redukcji wielkości zatrudnienia była o wiele mniejsza ${ }^{10}$. Po pierwsze wielu armatorów posiadało kilka jednostek rybackich i pomimo złomowania części posiadanych kutrów zachowali swoje miejsca pracy. Część rybaków, która zrezygnowała z zawodu, rozpoczęła nową działalność, głównie w obsłudze ruchu turystycznego. Niektórzy przeszli na emerytury. Tylko nieznaczna część zasiliła na stałe grono bezrobotnych ${ }^{11}$.

\section{Wielkość połowów morskich}

Głównym celem redukcji polskiej floty rybackiej, prócz zmniejszenia presji połowowej na ograniczone zasoby Morza Bałtyckiego, była poprawa rentowności połowów ${ }^{12}$. Wielkość zasobów możliwych do odłowienia miała być przydzielona mniejszej liczbie jednostek rybackich. W konsekwencji większe połowy przypadające na jednostkę rybacką miały zwiększyć dochodowość działalności. Tabela 3 przedstawia dane dotyczące połowów głównych gatunków ryb w wodach morza Bałtyckiego w roku 2004 oraz w roku 2013. Łączna wielkość zasobów ryb przyznanych do odłowienia polskiemu rybołówstwu w 2013 roku uległa zmniejszeniu o 34244 ton, czyli o niespełna 23\%. Natomiast w tym samym czasie liczebność floty rybackiej zmniejszyła się o 613 jednostek, czyli

\footnotetext{
wego klucza redukcji. Doprowadziło to do kasacji części jednostek rybackich relatywnie nowych oraz o większych gabarytach. W konsekwencji nie nastąpiło odmłodzenie polskiej floty rybackiej. Z kolei głęboka redukcja większych jednostek rybackich zachwiała jej strukturą połowową.

${ }^{9}$ Relatywnie większe ograniczenie zatrudnienia aniżeli liczebności floty rybackiej (odpowiednio 50,8 oraz $43,5 \%$ ) było konsekwencją wycofania $\mathrm{z}$ eksploatacji większych jednostek rybackich zatrudniających więcej osób.

${ }^{10}$ Trudno jednoznacznie określić faktyczny wzrost stopy bezrobocia wśród rybaków. Część bezrobotnych z czasem znajdowało pracę. Podejmowali ją zarówno w rybołówstwie (legalną oraz poza statystykami), jak i w innych sektorach gospodarki. Nieliczni zmienili miejsce zamieszkania.

${ }^{11}$ W SPO „Ryby 2004-2006” oraz PO „Ryby 2007-2013” zarezerwowane były środki na zmianę kwalifikacji dla rybaków. Ponadto rybacy z likwidowanych jednostek rybackich otrzymywali rekompensaty. Mogli przy tym po okresie jednego roku z powrotem wznowić działalność w sektorze połowów.

${ }^{12}$ Przy założeniu niezmienności pozostałych czynników wpływających na rentowność połowów. Są nimi głównie cena sprzedaży połowów oraz koszty działalności.
} 
Tabela 3

Charakterystyka polskich połowów głównych gatunków ryb morskich (tony) w roku 2004 oraz w roku 2013

\begin{tabular}{|c|c|c|c|c|c|c|c|c|c|c|}
\hline \multirow{4}{*}{$\begin{array}{c}\text { Gatunki } \\
\text { ryb }\end{array}$} & \multicolumn{10}{|c|}{ Lata } \\
\hline & \multicolumn{5}{|c|}{2004} & \multicolumn{5}{|c|}{2013} \\
\hline & \multirow{2}{*}{$\begin{array}{c}\text { Limit } \\
\text { połowowy }\end{array}$} & \multicolumn{2}{|c|}{ Połowy } & \multirow{2}{*}{$\begin{array}{c}\text { Liczba } \\
\text { jedno- } \\
\text { stek }\end{array}$} & \multirow{2}{*}{$\begin{array}{l}\text { Połowy/ } \\
\text { /jednostka }\end{array}$} & \multirow{2}{*}{$\begin{array}{c}\text { Limit } \\
\text { połowowy }\end{array}$} & \multicolumn{2}{|c|}{ Połowy } & \multirow{2}{*}{$\begin{array}{c}\text { Liczba } \\
\text { jednostek }\end{array}$} & \multirow{2}{*}{$\begin{array}{l}\text { Połowy/ } \\
\text { /jednostka }\end{array}$} \\
\hline & & tony & $\%$ & & & & tony & $\%$ & & \\
\hline Dorsze & 15825 & 15120 & 95,5 & 777 & 19,46 & 20733 & 12503 & 60,21 & 437 & 28,61 \\
\hline Szproty & 110880 & 96658 & 87,17 & 103 & 938,43 & 76680 & 80988 & 105,62 & 321 & 252,30 \\
\hline Śledzie & 28870 & 28410 & 98,41 & 464 & 61,23 & 23918 & 23560 & 98,50 & 657 & 35,86 \\
\hline Razem & 155575 & 140188 & 90,11 & 1344 & 99,57 & 121331 & 117051 & 96,47 & 1415 & 147,23 \\
\hline
\end{tabular}

Źródło: Opracowanie własne na podstawie: Rozporządzenie Ministra Rolnictwa i Rozwoju Wsi z dnia 12 grudnia 2003 roku w sprawie określenia organizmów morskich objętych ogólną kwotą połowową w 2004 roku oraz sposobu i warunków podziału tej kwoty (Dz.U. z 2003 r. nr 230, poz. 2306 oraz 2307); Informacja o podziale kwot połowowych na rok 2013 wprowadzona rozporządzeniem Ministra Rolnictwa i Rozwoju Wsi z dnia 23 grudnia 2011 roku w sprawie sposobu i warunków wykorzystania ogólnej kwoty połowowej (Dz.U. z 2011 r. nr 282, poz. 1653); Morska Gospodarka Rybna, MIR, Gdynia 2005; E. Kuzebski, 2005: Połowy..., op. cit.; Wykorzystanie kwot połowowych organizmów morskich w 2013 roku, zob. http://www.minrol.gov.pl/pol//nformacje-branzowe/Rybactwo/Rybolowstwo-morskie/Kwoty-polowowe (data dostępu: 28.03.2014).

o przeszło 43\% (tab. 2). Znacznie większa redukcja jednostek rybackich a niżeli limitów połowów powinna skutkować większymi połowami przypadającymi na jednostkę rybacką, i tym samym na poprawę rentowności sektora ${ }^{13}$. Sytuacja powinna wyglądać jeszcze lepiej, jeśli uwzględniłoby się faktyczne połowy, które w 2013 roku zmniejszyły się o niespełna 17\%, a stopień wykorzystania limitu połowowego wzrósł z 90,11\% w 2004 roku do 96,47\% w 2013 roku. Jednak w rzeczywistości rentowność połowów była zróżnicowana w zależności od gatunku ryb. Największy wzrost połowów przypadających na jednostkę pływająca nastapił w przypadku floty rybackiej specjalizującej się w połowach dorszy ${ }^{14}$.

\footnotetext{
${ }^{13}$ I tak w pierwszych latach po rozpoczęciu procesu redukcji floty rybackiej było. W 2007 roku wskaźnik rentowności wzrósł do 20\% z 2\% w 2004 roku. Zob. więcej E. Kuzebski, B. Marciniak, 2009: Mniej statków - więcej ryb?, MIR, Gdynia, s. 54-55.

${ }^{14}$ Chodzi o oficjalne połowy. Gdyby natomiast uwzględnić połowy nieraportowane, których skala była o wiele większa w 2004 roku, to wzrost kwoty połowowej na jednostkę rybacką nie jest już taki oczywisty. Szacuje się, że połowy przypadające na jednostkę rybacką wyniosły przeszło 83 tys. ton. W takiej sytuacji byłyby one wyższe aniżeli w 2013 roku, i to nawet przy pełnym wykorzystaniu limitu połowowego. Zob. więcej E. Kuzebski, 2005: Połowy polskiej floty rybackiej w 2004 roku, Wiadomości Rybackie 3-4(143), s. 7-9.
} 
Jednostki dorszowe w największym stopniu zostały dotknięte redukcją nakładu połowowego. Połowy dorszy zmniejszyły się natomiast nieznacznie i to przy wykorzystaniu limitu połowowego na poziomie $60 \% \mathrm{w}$ roku 2013. Główną przyczyną niskiego wykorzystania limitu połowowego był spadek opłacalności połowów. Ceny dorszy spadły na skutek ich nadpodaży na rynkach światowych oraz obniżenia się jakości dorszy bałtyckich - ryby były w złej kondycji, czego konsekwencją była ich niska wartość rynkowa. Pogorszyła się także relacja cenowa połowów. Bardziej opłacalne stały się połowy ryb pelagicznych, dlatego część floty dorszowej została przesunięta do połowów szprotów i śledzi. Wreszcie zbyt rozdrobniona i zaniedbana technicznie flota rybacka specjalizująca się w połowach dorszy nie była w stanie wykorzystać przyznanego Polsce limitu połowowego. Jak już wspomniano, z eksploatacji wycofano znaczną część jednostek stanowiących trzon polskiego rybołówstwa. Możliwości techniczne pozostałej w eksploatacji floty były niewystarczające, aby wypełnić powstałą lukę.

W przypadku ryb pelagicznych połowy przypadające najednostkęw 2013 roku uległy zmniejszeniu. Było to następstwem przyznanych Polsce niższych limitów połowowych i tym samym mniejszych połowów. Jednocześnie krajowa flota rybacka stała się bardziej uniwersalna. Dzięki procesowi restrukturyzacji i modernizacji z wykorzystaniem środków unijnych duża jej część uczestniczy jednocześnie w połowach trzech głównych gatunków ryb ${ }^{15}$. Natomiast w 2004 roku na początku procesu restrukturyzacji jednostki rybackie specjalizowały się w połowach jednego gatunku ryb. W związku z czym, przy określeniu wielkości połowów w 2013 roku przypadających na jednostkę rybacką, należałoby uwzględnić wszystkie trzy gatunki ryb. Ponadto, w przeciwieństwie do dorszy, połowy ryb pelagicznych stały się bardziej opłacalne. Było to następstwem zmniejszenia ich podaży na rynku krajowym (m.in. na skutek przyznania niższych limitów połowowych) oraz poprawy rentowności ich połowów. Jednostki prowadzące połowy pelagiczne, a szczególnie największe z nich, zostały w ostatnich latach zmodernizowane. Wyposażono je w nowoczesne urządzenia do przechowywania połowów na pokładzie, co wpłynęło na poprawę jakości surowca, a w konsekwencji na wysokość cen zbytu. Duża popularność wśród rybaków połowów ryb pelagicznych doprowadziła do szybkiego wykorzystania przyznanych limitów połowowych ${ }^{16}$. Konsekwencją było wstrzymanie przez Ministerstwo Rolnictwa i Rozwoju Wsi połowów ryb pelagicznych w obawie przed ich dalszym przełowieniem.

\footnotetext{
${ }^{15}$ Redukcja floty rybackiej w największym stopniu dotknęła największe jednostki. Zmniejszenie ich możliwości połowowych umożliwiło połowy ryb pelagicznych przez mniejsze statki niespecjalizujące się dotąd $\mathrm{w}$ ich połowach.

${ }^{16} \mathrm{~W}$ przypadku śledzi limity połowowe wykorzystano w niemal $100 \%$, natomiast $\mathrm{w}$ przypadku szprotów nawet je przekroczono, ze względu na możliwość ich przełowienia.
} 


\section{Finansowanie portów i przystani rybackich ze środków unijnych}

W tabeli 4 przedstawiono dane dotyczące finansowania portów i przystani rybackich ze środków unijnych w latach 2004-2013. Łączna wielkość środków przeznaczona na ten cel wyniosła 188528 tys. euro. Fundusze cieszyły się dużym zainteresowaniem beneficjentów, co potwierdza olbrzymie potrzeby inwestycyjne zaniedbanych przez dziesięciolecia portów i przystani rybackich.

\section{Tabela 4}

Charakterystyka finansowania [tys. euro] portów oraz przystani rybackich w latach 2004$-2013$

\begin{tabular}{|c|c|c|c|c|c|c|}
\hline \multicolumn{3}{|c|}{ Wielkość środków } \\
\hline \multicolumn{3}{|c|}{ SPO „Ryby 2004-2006” } & \multicolumn{3}{c|}{ PO „Ryby 2007-2013” } \\
\hline $\begin{array}{c}\text { początkowa } \\
\text { alokacja }\end{array}$ & $\begin{array}{c}\text { końcowa } \\
\text { alokacja }\end{array}$ & $\begin{array}{c}\text { \% złożonych } \\
\text { wniosków }\end{array}$ & $\%$ płatności & $\begin{array}{c}\text { alokacja } \\
\text { środków }\end{array}$ & $\begin{array}{c}\text { \% złożonych } \\
\text { wniosków }\end{array}$ & $\%$ płatności \\
\hline 28723 & 42341 & 196,04 & 95,73 & 143187 & 215,92 & 100 \\
\hline
\end{tabular}

Źródło: Opracowanie własne na podstawie: Sektorowy Program Operacyjny „Rybołówstwo i przetwórstwo ryb 2004-2006”. Ocena realizacji Sektorowego Programu Operacyjnego „Rybołówstwo i przetwórstwo ryb 2004-2006”. Informacja o postępach..., op. cit.

W SPO „Ryby 2004-2006” początkowa wielkość alokacji wyniosła 28723 tys. euro. W trakcie realizacji okazała się ona niewystarczająca w stosunku do zgłaszanych potrzeb, w związku z czym wielkość środków została podniesiona do 42341 tys. euro. Wartość złożonych wniosków o dofinansowanie inwestycji przekroczyła o blisko 97\% pulę dostępnych środków. Dlatego też w PO „Ryby 2007-2013” na modernizację portów i przystani rybackich zarezerwowano środki wielokrotnie przewyższające wielkość alokacji z SPO „Ryby 2004-2006". Pomimo tego zostały one w pełni wykorzystane, wartość wniosków złożonych w ramach PO „Ryby 2007-2013” wyniosła 215,92\% dostępnych środków. Potwierdza to potrzebę dalszej modernizacji portów i przystani rybackich, albowiem proces ich unowocześniania nie został zakończony ${ }^{17}$.

Inwestycje finansowane ze środków unijnych zostały zrealizowane we wszystkich portach oraz w większych przystaniach rybackich. Dzięki funduszom sektorowych programów operacyjnych nastapiła poprawa stanu technicznego infrastruktury portowej. Porty i przystanie rybackie oraz miejsca wyładunku zo-

\footnotetext{
${ }^{17}$ Więcej na temat finansowania struktur rybackich: J. Zieziula, P. Nowaczyk, 2011: Wybrane aspekty funkcjonowania morskich portów rybackich w Polsce, PTE, Szczecin, s. 105-119.
} 
stały wyposażone w nowoczesne urządzenia i obiekty niezbędne do prawidłowego funkcjonowania. Środki unijne były głównym, a w niektórych przypadkach jedynym źródłem finansowania inwestycji. Bez pomocy unijnej wiele z nich nie doszłoby do skutku. W przypadku niektórych struktur portowych gruntowna modernizacja była pierwszą od ich powstania. Następstwem inwestycji było zwiększenie bezpieczeństwa postoju jednostek rybackich, poprawiły się warunki przeładunku, magazynowania oraz dystrybucji połowów morskich.

\section{Potrzeba dalszych zmian w polskim rybołówstwie morskim}

Pomimo wielu zmian proces restrukturyzacji polskiego rybołówstwa morskiego nie został zakończony. Polska flota rybacka w analizowanym okresie (lata 2004-2013) uległa znacznej redukcji. Trudno jednoznacznie stwierdzić, czy skala redukcji jest adekwatna do wielkości zasobów morza Bałtyckiego, tym bardziej, że występują problemy z dokładnym ich określeniem. Ponadto wielkość zasobów ryb w Bałtyku ulega ciągłym zmianom. Wśród armatorów występuje jednak chęć dalszej redukcji jednostek rybackich. Tym bardziej iż środki unijne z przeszłego Europejskiego Funduszu Morskiego i Rybackiego (EFMR) na lata 2014-2020 przewidują możliwość wypłacania rekompensat finansowych za wycofanie jednostki rybackiej z eksploatacji. Jednakże skala pomocy w nadchodzącym sektorowym programie operacyjnym będzie z pewnością niewspółmiernie mniejsza od dotychczasowej, szczególnie w Polsce. $Z$ drugiej jednak strony środki unijne można wykorzystać do łagodzenia bezrobocia wśród rybaków.

Argumentem przemawiającym do rybaków za pozostaniem w zawodzie mogą być działania zmierzające do poprawy w przyszłości stanu zasobów ryb bałtyckich. Od 2015 roku wprowadzono obowiązek zagospodarowanie przyłowu ryb, a eksploatacja zasobów morskich ma się odbywać na poziomach pozwalających na odbudowę i zachowanie populacji poławianych gatunków ${ }^{18}$.

W przypadku dorszy należałoby zwiększyć stopień wykorzystania limitów połowowych, które w ostatnich latach były na niskim poziomie. Wspólna Polityka Rybacka ma ograniczony wpływ na czynniki naturalne. Może jednak wpływać na efektywność połowów przez dofinansowanie modernizacji jednostek rybackich. Uzyskanie wyższych cen zbytu oraz lepsze wykorzystanie limitów połowowych może nastapić $\mathrm{w}$ wyniku poprawy organizacji rynku rybnego. Or-

\footnotetext{
${ }^{18}$ Prognoza oddziaływania na środowisko projektu Programu Operacyjnego „Rybactwo i Morze” (uzupełnienie), http://www.minrol.gov.pl/Informacje-branzowe/Rybactwo/Aktualnosci/Konsultacje-Uzupelnienie-prognozy-oddzialywania-na-srodowisko-projekt (data dostępu: 20.05.2015).
} 
ganizacje producenckie skupiające armatorów w celu niedopuszczenia do nadmiernego obniżenia cen mogą skupować ryby po tzw. cenie wycofania. $Z$ kolei przekazywanie kwot połowowych między armatorami może przyczynić się do efektywniejszego zarządzania połowami. Tak samo jak uzależnienie wysokości indywidualnych kwot połowowych od faktycznie dokonywanych połowów ${ }^{19}$.

W przypadku połowów ryb pelagicznych największym problemem jest zbyt szybkie wykorzystywanie limitów połowowych, czego następstwem jest wstrzymywanie połowów. W celu bardziej równomiernego rozłożenia połowów w 2014 roku zostały wprowadzone indywidualne kwoty połowowe. Armatorzy już nie będą intensyfikować połowów w pierwszych miesiącach sezonu w obawie przed zbyt przedwczesnym wykorzystaniem przyznanego Polsce limitu połowowego. Ograniczy to także znaczne spadki cen w okresach koncentracji połowów. Wszystkie proponowane lub wprowadzone zmiany są następstwem reformy $\mathrm{WPR}^{20}$. Ich realizację ułatwią środki unijne.

Nowy program operacyjny (EFMR) na lata 2014-2020 przewiduje także kontynuację finansowania portów i przystani rybackich ${ }^{21}$, których proces modernizacji nie został w Polsce zakończony. Ze względu na wysoką kapitałochłonność inwestycji, szczególnie infrastrukturalnych, środki unijne nadal będą stanowić główne źródło ich finansowania.

\section{Wnioski}

1. Wobec zmniejszających się zasobów ryb w Bałtyku proces restrukturyzacji nadmiernie rozbudowanej floty rybackiej był nieuchronny. Dzięki środkom unijnym proces ten przyśpieszono oraz ograniczono jego negatywne konsekwencje.

2. Dostępność środków unijnych uruchomiła intensywny proces inwestycyjny w portach rybackich, prowadząc do ich unowocześnienia.

3. Wycofanie z eksploatacji znacznej części polskiej floty rybackiej przyczyniło się do wzrostu połowów przypadających na jednostkę rybacką.

\footnotetext{
${ }^{19}$ Więcej na temat zmian w polskim rybołówstwie morskim będących następstwem reformy WPR: H. Bierndgarski, 2013: Zmiany w ustawie o rybołówstwie morskim, Magazyn Przemysłu Rybnego 1(91).

${ }^{20}$ Więcej na temat reformy WPR: Parlament Europejski zatwierdził Wspólna Politykę Rybołówstwa, http://www.portalmorski.pl/rybolowstwo/36184-parlament-europejski-zatwierdzil-wspolna-polityke-rybolowstwa (data dostępu: 28.03.2014).

${ }^{21}$ PO „Rybactwo i Morze” przewiduje możliwość finansowania: portów rybackich, giełd rybnych, miejsc wyładunku i przystani oraz urządzeń i obiektów do odbioru i zagospodarowania przyłowu.
} 
4. Najmniejsze zainteresowanie połowami dorszy wynikało ze spadku cen ich zbytu oraz ograniczonych możliwości połowowych rozdrobnionej i zaniedbanej technicznie floty rybackiej.

5. Największy wzrost połowów zaobserwowano w przypadku ryb pelagicznych, co wynikało z poprawy opłacalności ich sprzedaży oraz wzrostu efektywności połowowej.

6. Proces restrukturyzacji krajowego rybołówstwa morskiego nie został zakończony. Wysokie nakłady inwestycyjne na modernizacje infrastruktury portowej oraz konieczność dalszej redukcji floty rybackiej powodują, że w najbliższej przyszłości podstawowym źródłem finansowania zmian w rybołówstwie morskim pozostaną środki unijne z sektorowego programu operacyjnego (EFMR) na lata 2014-2020.

\section{Literatura}

BIERNDGARSKI H., 2013: Zmiany w ustawie o rybołówstwie morskim, Magazyn Przemysłu Rybnego 1(91), 37.

BLADY W., NETZEL J., 2005: Połowy bałtyckiego dorsza w polskim rybołówstwie w latach 1921-2003, Wiadomości Rybackie 1-2(143), 12-15.

BROCKI W., 2000: Ogólna charakterystyka wspólnej polityki rybackiej, [w]: Wybrane zagadnienia wspólnej polityki rybackiej w Unii Europejskiej - potrzeby i możliwości adaptacji wspólnej polityki rybackiej przez polska gospodarke rybna, (red.) J. Zieziula, Wydawnictwo Ekspert - SITR, Koszalin, s. 9-17.

DUNIN-KWINTAI., 2000: Wielowariantowy model redukcji nakładu połowowego z uwzględnieniem skutków społecznych w rejonach nadmorskich, [w]: Wybrane zagadnienia wspólnej polityki rybackiej w Unii Europejskiej - potrzeby i możliwości adaptacji wspólnej polityki rybackiej przez polska gospodarke rybna, (red.) J. Zieziula, Wydawnictwo Ekspert - SITR, Koszalin, s. 47-48.

GRZELAKOWSKI A.S., 2002: Bariery i szanse rozwoju małych portów morskich polskiego wybrzeża w perspektywie akcesji do UE, [w]: Małe porty polskiego wybrzeża - stan obecny i perspektywy ich rozwoju, (red.) A.S. Grzelakowski, K. Krośnicka, Wydawnictwo Akademii Morskiej w Gdyni, Gdynia, s. 9-24.

HRYSZKO K.: Polacy nadal jedzq mało ryb. Szanse na znaczacy wzrost spożycia sq niewielkie, http://www.biznes.newseria.pl/news/polacy_nadal_jedza_malo,p1522677165 (data dostępu: 20.05.2015).

Informacja o podziale kwot połowowych na rok 2013 wprowadzona rozporządzeniem Ministra Rolnictwa i Rozwoju Wsi z dnia 23 grudnia 2011 roku w sprawie sposobu i warunków wykorzystania ogólnej kwoty połowowej (Dz.U. z 2011 r. nr 282, poz. 1653).

Informacji o postępach wdrażania Programu Operacyjnego „Zrównoważony rozwój sektora rybołówstwa i nadbrzeżnych obszarów rybackich 2007-2013" (stan na styczeń 2014 roku).

KUZEBSKI E., 2005: Połowy polskiej floty rybackiej w 2004 roku, Wiadomości Rybackie 3-4(143), 7-9. 
KUZEBSKI E., MARCINIAK B., 2009: Mniej statków - więcej ryb?, MIR, Gdynia, 54-55. MALKOWSKA A., 2010: Droga ku zrównoważonemu rybołówstwu Morza Battyckiego na przyktadzie Polski, [w]: XXV Sejmik Morski, Zeszyty Naukowe 589, Ekonomiczne Problemy Usług 49, Wydawnictwo US, Szczecin, 275-285.

MARCINIAK B., 2008: Zamierzenia i realia, Wiadomości Rybackie 7-8(164), 12-17.

Ocena realizacji Sektorowego Programu Operacyjnego „Rybołówstwo i przetwórstwo ryb 2004-2006”, https://bip.minrol.gov.pl/Informacje-Branzowe/Rybolowstwo/Ocena-expost-SPO-Rybolowstwo-i-przetworstwo-ryb-2004-2006 (data dostępu: 25.03.2014).

Parlament Europejski zatwierdził Wspólna Politykę Rybołówstwa, http://www.portalmorski. pl/ rybolowstwo/36184-parlament-europejski-zatwierdzil-wspolna-polityke-rybolowstwa (data dostępu: 28.03.2014).

PIEŃKOWSKA B., 2009: Pomoc finansowa dla sektora rybołówstwa w okresie programowania 2007-2013, Wiadomości Rybackie 5-6(169), 12-13.

PIEŃKOWSKA B., HRYSZKO K., 2013: Spożycie ryb, Rynek Ryb 20, 26-30.

POLAŃSKI Z., 2000: Polskie rybołówstwo przybrzeżne, MIR, Gdynia, 52-56.

Prognoza oddziaływania na środowisko projektu Programu Operacyjnego „Rybactwo i Morze" (uzupełnienie), http://www.minrol.gov.pl/Informacje-branzowe/Rybactwo/Aktualnosci/Konsultacje-Uzupelnienie-prognozy-oddzialywania-na-srodowisko-projekt (data dostępu: 20.05.2015).

Program Operacyjny „Zrównoważony rozwój sektora rybołówstwa i nadbrzeżnych obszarów rybackich 2007-2013", http://www.minrol.gov.pl/Wsparcie-rolnictwa-i-rybolowstwa/PO-RYBY-2007-2013 (data dostępu: 25.03.2014).

Rozporządzenie Ministra Rolnictwa i Rozwoju Wsi z dnia 12 grudnia 2003 roku w sprawie określenia organizmów morskich objętych ogólną kwotą połowową w 2004 roku oraz sposobu i warunków podziału tej kwoty (Dz.U. z 2003 r. nr 230, poz. 2306 oraz 2307).

Sektorowy Program Operacyjny „Rybołówstwo i przetwórstwo ryb 2004-2006”, http:// www.minrol.gov.pl/Wsparcie-rolnictwa-i-rybolowstwa/Fundusze-Strukturalne/SPORybolowstwo-i-Przetworstwo-Ryb (data dostępu: 25.03.2014).

SZOSTAK S. 2005: Morska Gospodarka Rybna, MIR, Gdynia, 1-8.

Wykorzystanie kwot połowowych organizmów morskich w 2013 r. (data dostępu: 28.03.2014).

ZIEZIULA J., NOWACZYK P., 2011: Wybrane aspekty funkcjonowania morskich portów rybackich $w$ Polsce, PTE, Szczecin, 105-119.

\section{Abstrakt}

Polska po przystąpieniu do Unii Europejskiej została objęta regulacjami Wspólnej Polityki Rybackiej, czego następstwem była restrukturyzacja polskiego rybołówstwa morskiego na niespotykaną dotychczas skalę. Zmiany objęły flotę połowową oraz porty rybackie.

Od 2004 roku rozpoczął się intensywny proces redukcji polskiej floty rybackiej, której potencjał był zbyt duży do stale zmniejszających się zasobów ryb bałtyckich. Wycofanie z eksploatacji znacznej części floty rybackiej zmniejszyło presje na połów zagrożonych przełowieniem gatunków ryb oraz zwiększyło kwo- 
ty połowowe dla pojedynczych jednostek rybackich. Negatywną konsekwencją zmian było zmniejszenie zatrudnienia w sektorze połowów, jednak tylko nieliczni z rybaków na stałe stracili pracę.

Zaniedbywane inwestycyjnie przez lata porty i przystanie rybackie dzięki środkom unijnym zostały unowocześnione. Dokonano modernizacji zdekapitalizowanej infrastruktury. Poprawily się warunki postoju jednostek rybackich w portach. Struktury rybackie wyposażono w niezbędne urządzenia i obiekty. Przyczyniły się one do poprawy warunków przeładunku, magazynowania oraz dystrybucji połowów morskich.

Bilans dotychczasowego dziesięcioletniego członkostwa Polski w Unii Europejskiej dla polskiego rybołówstwa morskiego należy ocenić pozytywnie. Krajowe rybołówstwo morskie wymagało wielu zmian. Integracja europejska tylko przyśpieszyła proces restrukturyzacji, jednocześnie łagodząc jego negatywne skutki. Należy w przyszłości oczekiwać kontynuacji pozytywnego trendu zmian w polskim rybołówstwie morskim.

Słowa kluczowe: integracja europejska, rybołówstwo morskie, restrukturyzacja sektora rybackiego

\section{The effects of the Polish EU membership on the national sea fishing}

\section{Abstract}

After its accession to the EU, Poland became subject to the regulations of the Common Fishery Policy and as a result Polish sea fishing underwent restructuring on an unprecedented scale. The changes included the fishing fleet and the fishing seaports.

An intensive process of reducing Polish fishing fleet, whose potential was too large in relation to the continually decreasing fish resources in the Baltic Sea, began in 2004.

As a significant number of fishing vessels were removed from service, the pressure on fishing for species endangered with overfishing diminished, while the fishing quotas for individual fishing vessels increased. A negative consequence of these changes were reductions in employment in the fishing sector, however, only a few fishermen lost their jobs permanently.

Ports and harbors, which had been neglected in terms of the investments made, were modernized owing to EU funding. The decapitalized infrastructure 
was modernized, and the mooring conditions for vessels stopping at seaports improved. Necessary equipment and objects were provided for fishing structures, which contributed to the improvement in the conditions of transshipment, storage, and distribution of sea fishing.

The assessment of Poland's hitherto ten-year membership in the EU and its effects on Polish sea fishing should be positive. Polish sea fishing sector required changes. European integration only accelerated the restructuring process while simultaneously mitigating its negative effects. The continuation of the positive trend of changes in the national sea fishing is to be expected.

Key words: European integration, sea fishing, restructuring of the fishery sector 
